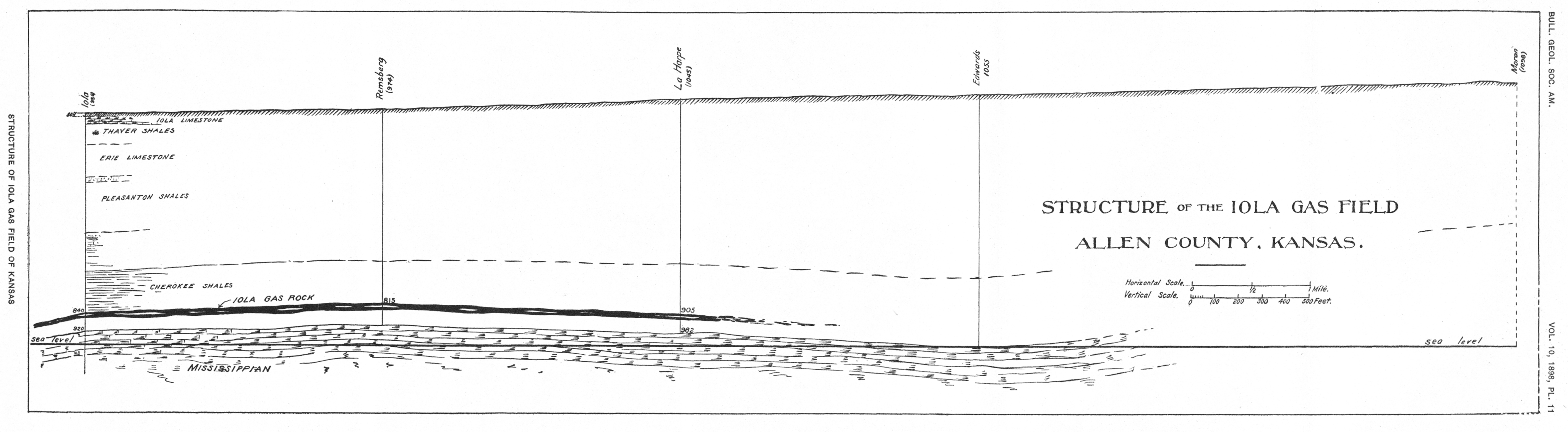




\title{
GEOLOGICAL STRUCTURE OF THE IOIA GAS FIELD
}

\author{
BY EDWARD ORTON
}

(Read before the Society December 30, 1898)

CONTENTS

Introduction

Abundance and geologic relations of gas rock . . . . . . . . . . . . 100

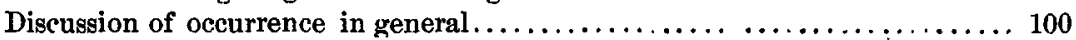

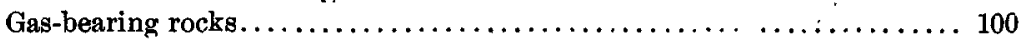

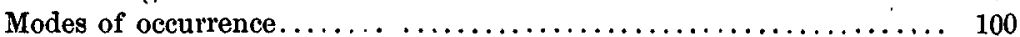

The classes $\ldots \ldots \ldots \ldots \ldots \ldots \ldots \ldots \ldots \ldots \ldots \ldots \ldots \ldots \ldots \ldots \ldots \ldots \ldots$

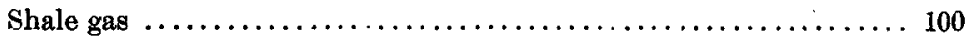

Reservoir gas................................ 101

Anticline and terrace $\ldots \ldots \ldots \ldots \ldots \ldots \ldots \ldots \ldots \ldots \ldots \ldots \ldots \ldots \ldots$

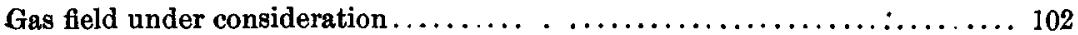

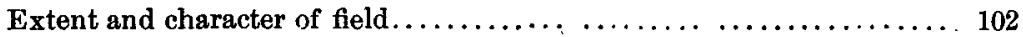

Geology of the region $\ldots \ldots \ldots \ldots \ldots \ldots \ldots \ldots \ldots \ldots \ldots \ldots \ldots \ldots \ldots$

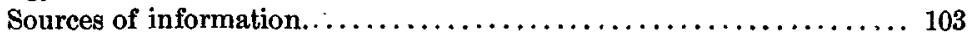

The formations . . . . . . . . . . . . . . . . . . . . . . 103

Coal Measures and sub-Carboniferous limestone. . . . . . . . 103

Cherokee shales. . . . . . . . . . . . . . . . . . . . . 103

Other divisions............................ 104

Iola gas rock. ................................... 104

Iola arch at Edwards well. ....................... 104

Structure as a factor in interpretation $\ldots \ldots \ldots \ldots \ldots \ldots \ldots \ldots \ldots \ldots$

Economic value. .............................. 105

\section{INTRODUC'TION}

In this country, at least, natural gas is advancing rather rapidly in public appreciation and regard. It is found to be much more widely distributed, both geographically and geologically, and to exist in much larger quantity than any one would have ventured to claim 20 or even 10 years ago. It is no longer an unusual thing for a village or city to enjoy a more or less adequate supply of natural gas as a source of artificial heat and light. There are many such examples in New York, 
Pennsylvania, Ohio, West Virginia, Kentucky, Indiana, Mlinois, and Kansas.

Abundance and geologic Relations of Gas Rock

As to its productive horizons, there is hardly a stratum in the Paleozoic column of the country that is not somewhere, in some of its phases or conditions, a gas rock.

\section{Discussion of Occurrence in General}

\section{GAS-BEARING ROCKS}

While it occurs in shales, sandstones, conglomerates, limestones, and dolomites, it still remains true that it has its preferences and that its great accumulations are to be found only in certain kinds of strata.

\section{MODES OF OCCURRENCE}

The classes.-Two distinct modes of its occurrence are to bə recognized : That which prevails in shales and in certain limestones, and that which is found in sandstones, conglomerates, and in a certain class of dolomitic limestones. The rocks of the first group are generally counted impervious, while the porosity of the second group is universally recognized.

The gas found in the first group may be provisionally termed shale gas; that of the second group may be provisionally styled reservoir gas. These terms are obviously open to criticism and objection, but no other simple terms have been suggested that will avoid the apparent contradictions or erroneous assumptions of those here proposed.

Shale gas.-Gas wells in the two classes of strata named above are sharply distinguished from each other.

1. Shale gas wells are generally of comparatively small volume.

2. They lack uniformity of rock pressure. Wells drilled in close proximity and to the same depth may show very different figures on the pressure gauge.

3. There is no definite horizon from which their gas supply is derived. The stratum that yields it may be several hundred feet thick, and gas is likely to be found at any point in the descent. Shale gas wells, though in the same field, may be expected to show a considerable range in depth.

4. Shale gas wells often occur independently of oil production. Gas may be abundant, while petroleum is altogether wanting. No large oil fields are known in connection with shale gas.

5. Shale gas has good staying properties. Weak flows are maintained for long periods. Most of the gas springs that have been flowing from immemorial time are to be referred to this division.

6. Shale gas is not dependent on the structural arrangement of the rocks which contain it. Not being associated with oil or water, it cannot be displaced or crowded out by them. 
Reservoir gas.-The characteristics of reservoir gas or the gas of porous rocks may be pretty fairly made out by reversing the several statements made for shale gas.

1. The largest knoun gas wells-those, for example, whose volumes run up to tens of million of cubic feet a day-are all found in sardstones, conglomerates, and porous dolomites.

2. In a gas field fed by a porous rock the wells attain the same pressure, approximately, irrespective of their widely differing volumes. The normal pressure can generally be obtained from one well as safely as from another.

3. In reservoir wells the gas is found at definite horizons. The driller soon learns the depth to which a well must be carried. If he does not find his reward at a certain point in the descent, he knows that he is to go unrewarded altogether.

4. In reservoir wells oil accompanies the gas in multitudes of instances. These porous rocks are the great repositories of petroleum the world over. With the petroleum, water is in variably associated. The principle that the philosophers of the sixteenth century asserted so positively, that "nature abhors a vacuum," applies with special force to porous rocks. They are in the large way filled with water, usually with salt water; but the other substances above named, gas and oil, occupy certain limited portions of these porous beds.

5. The gas of these porous rocks oflen, I may say generally, comes to a sudden end. Oil comes in and fills the pipes, or salt water shuts off the gas like a light blown out by a gust of wind. Only by constant care and attention in removing these substances from the pipes can the life of the well be maintained, especially in its later stages.

6. The structure or arrangement of the strata is found to be the dominant feature in the gas production of porous rocks. Not only is a particular kind of rock demanded for the accumulation of gas, but the accumulation is strictly limited to certain portions of the stratum

\section{ANTICLINE AND TERRACE}

Two well known structural features are especially connected with the accumulation of oil and gas, namely, the anticline and the terrace. Both of these have passed, in this connection, beyond the theoretical stage. Their value in the way of petroliferous accumulation is no longer discussed as a possibility, but has been abundantly demonstrated as a matter of fact. A few geologists and oil producers, having the knowledge by which they can read these structures from the surface, are reaping rich rewards by the application of this knowledge.

A few years ago, while controversy as to the possible effect of anticlines was still in progress, some reputable geologists, who happened to be ranged on the wrong side of the question, declared that, instead of gas being confined to anticlines, it was often found in the synclines of porous strata. To them it was replied that we occasionally see on the surface 
an extensive syncline interrupted by a minor anticline at the bottom of the trough, and that such structure would fully account for the rare cases in which short-lived gas wells are found in synclines. The physical impossibility of gas occurring in the actual syncline of a porous stratum which is jointly occupied by gas and salt water is so obvious that to be recognized it needs only to be named.

The terrace is an incomplete anticline or arch. It is as if nature began to build an arch which she was unable to finish; but like its prototype, the arch, it furnishes a safe harbor or gathering ground for the lighter contents of the warped porous stratum.

It seems to me that the time has now come for the prompt recognition and acknowledgment of the paramount influence of structure in gas fields which are found in porous rocks. We are warranted in affirming an anticline or terrace as an explanation of the gas production of such a stratum, even in advance of the actual discovery of either.

\section{Gas Field under Consideration}

\section{EXTENT AND CHARACTER OF FIELD}

This line of thought has been suggested to me by an examination that I have recently made of the gas field of Allen county, southeastern Kansas, which is known as the Iola gas field. It is small in area, but of great promise in production. Its length in an east-and-west line has been demonstrated by the drill to be at least seven miles, while its breadth, proved in the same way, has been found to exceed three miles.

More than two dozen wells have already been drilled in the field, and the wells range in production from two million to over ten million feet in 24 hours. There are a half dozen of the number, each of which produces about $7,000,000$ feet a day.

The rock pressure of the field is 325 pounds, with an outside range of five pounds in a single well.

A little oil has been found, mainly on the western boundary of the field and at a lower depth than the gas. Salt water occurs below both gas and oil, but has not proved thus far aggressive. The height to which it rises has not been determined. It is not less than several hundred feet.

The gas rock is a sandstone of moderate grain, with an average thickness of about 20 or 25 feet. It is occasionally interrupted by wedges of shale, and disappears as a sandstone altogether beyond the boundaries I have named.

All these characteristics stand for a gas field in the second division 
above named. Every feature of the Iola field indicates a porous or reservoir rock as the source of its gas.

\section{GEOLOGY OF THE REGION}

Sources of information.-The geology of southeastern Kansas is comparatively simple. In describing it I rely mainly on the published reports of the geological survey conducted by the state university under the direction of Professor Erasmus Haworth.

The formations-Coal Measures and sub-Carboniferous limestone.-All strata reaching the surface in this section of the state belong to the socalled Coal Measures, with the single exception of the great sub-Carboniferous limestone, which may be regarded as the floor of the eastern half of Kansas. This stratum rises today only in the southeastern angle of the state, and its outcrop does not exceed 45 square miles; but though small in area, it has extreme economic interest and importance, for it carries zinc and lead ores in large quantities. As a source of the former, this 45 square miles is beyond question the most valuable tract known in the United States. Perhaps no equal area in the world exceeds it in this respect. This sub-Carboniferous stratum is coming to be known in Kansas and the adjoining states as the Mississippian limestone. In sinking deep wells it constitutes a particularly valuable landmark, because its flinty beds are certain to attract the driller's notice and are universally regarded by him in his search for petroleum as the "farewell rock." When he strikes this floor he knows that his work is done.

There are large areas of Kansas and adjoining states in which the Coal Measures, so called, do not justify their name. In many long sections furnished by the drill they are found to consist altogether of vimestone, shale, and sandstone; but in other districts the series contain important beds of coal, the aggregate of which, as computed, runs into large figures, and constitute an invaluable reliance of all these regions for time to come.

The western Coal Measures have been variously divided by the geologists who have studied them in the several states. It is a pleasure to find that they are coming to a general agreement, which promises at no distant day a harmonious account of this great chapter of our geological history.

Cherokee shales.-In southeastern Kansas, the lowermost division of the Coal Measures, namely, that immediately overlying the Mississippian limestone, is known as the "Cherokee shales." It is counted the equivalent of the "Des Moines shales" of Keyes in Iowa. The Cherokee shales have a thickness of about 450 feet and contain, in certain districts, by far the most valuable seams of coal found in Kansas. Though con- 
sisting largely of shale, as the name would lead us to expect, thin courses of limestone and considerable bodies of sandstone also occur in it. Some of the sandstones rise in important and valuable outcrops; but other beds begin and end in the shale series, and for our knowledge of them we are indebted wholly to the driller. They are capricious and unstable to a high degree.

Other divisions.-A bove the Cherokee shales come several well marked and easily identified divisions known in Kansas geology as the "Oswego and the Pawnee limestones," about 100 feet in combined thickness, the "Pleasanton shales," about 250 feet thick and carrying in certain localities valuable beds of coal, the "Erie limestone and shale," the "Thayer shale," and the "Iola limestone," together aggregating several hundred feet of strata.

The divisions here named comprise all the strata traversed in the wells of the Iola gas field.

Iola gas rock--The gas rock already described is one of the unstable, lenticular sandstones of the Cherokee shale, and lies near the bottom of this division. Its upper surface is above 75 feet above the Mississippian limestone.

All these strata are described by Haworth as dipping to the west at an average rate of 17 feet to the mile.

The surface of this portion of the state also slopes to the west, but not as rapidly as the strata descend. The surface slope to the westward is given by Haw orth as about 10 feet to the mile. These facts are indicated in the accompanying diagram (plate 11). The elevation of Iola is 956 feet above tide; of Laharpe, 5 miles to the eastward, 1,045 feet, and of Moran, 12 miles east of Iola, 1,098 (see Gannett's Gazetteer of Kansas). This gives an average descent from Moran to Iola of nearly 12 feet to the mile. Other elevations used in this paper were obtained from the aneroid and can not vary far from the true figures.

Iola arch at Edwards well.-At the Edwards well, two miles beyond Laharpe, the Iola gas rock has completely disappeared as a sandstone, but the driller continued his work unitil he reached the Mississippian limestone, or the "flint," as it is commonly called. This was reached at 1,061 feet, or very nearly at tide level. The same stratum was also struck in one of the wells at Laharpe, but here at a depth of 982 feet, or 63 feet above tide, showing a rise to the westward of 31 feet to the mile in place of the normal descent in that direction of 17 feet to the mile.

A low arch, which may, perhaps, with greater propriety be styled a terrace, thus comes into view. So far as present knowledge goes, the arch begins at the location of the Edwards well, in which, as will be remembered, the surface of the Mississippian limestone lies at tide level. 
The stratum rises to the westward from this point and does not regain tide level until it is followed about 2 miles beyond Iola. At Iola its place is calculated to be 37 feet above tide.

We have thus a stretch of territory about 8 miles in length from east to west in which there is no fall to the Mississippian floor of the section. Its normal dip of 17 feet to the mile would carry it 126 feet below tide in that distance.

The gas rock is not coextensive with the arch, as, it will be remembered, it fails to appear in the Edwards well. If it had continued to that point in its normal volume, its upper surface would have been found 77 feet above tide.

At Laharpe, however, it is found in full force, and its surface here is 140 feet above tide, as determined by the average of two 905 -foot wells. It rises 19 feet higher in the next 3 miles, being found at 159 feet above tide in the Remsberg well. This is the highest point of the Iola gas rock, so far as explorations have now gone, and it is interesting to note that this well is the largest producer of gas in the entire field. Its volume exceeds ten million cubic feet a day, which is about three million in excess of any other well in the field. The surface of the gas rock descends 43 feet in the next two miles to the westward. The average depth to the gas rock of two wells at Iola is 840 feet, which shows its surface to be $\mathbf{1 1 6}$ feet above tide. Within the next two miles the Mississippian limestone gets down to tide level again, and this point marks the limit of the Iola arch.

STRUCTURE AS A FACTOR IN INTERPRETATION

It is thus seen that the Iola gas field comes fully into line with a large number of other gas fields that belong to the same class with it. In all of these, structure is the dominant factor, a factor which helps us to a rational explanation of the characteristic phenomena of all.

\section{ECONOMIC VALUE}

A word as to the use which is to be made of the Iola gas field. It seems certain that it will be devoted in the wholesale way to manufacturing purposes. The zinc smelters of the Joplin district found their way into the gas field almost as soon as its valuable character was established. They bought and leased gas lands wherever they could be secured, and thus, without holding a large acreage, they have gained access to all parts of the field. Five or six large plants are already established here. The experimentation necessary to adapt the fuel to the process has already been successfully accomplished, and the smelters now report the best of results. Others are sure to come in to secure the 
great advantages of the new fuel. As in the glass industry of the country, after the opening of the Ohio and Indiana gas fields, the center of the manufacture was shifted, so it seems likely to be with the spelter production. The old districts will be unable to compete and will be left to languish as long at least as the gas supply can be maintained. The cities and villages of Allen county will be supplied with light and fuel, and many of the farmers' houses also, within the limits of the field; but the great bulk of this superfine fuel, the best in the world-much better, in fact, than man has learned to make for use in the large way-will be consumed in smelting zinc ores, for which, until this gas was discovered, even inferior grades of Kansas coal were counted good enough.

The highest and really the only proper use of natural gas is household use. In this field it meets the supreme test of doing the greatest good to the greatest number. If the world were wise and if genuine good will controlled the actions of all, every foot of natural gas would be scrupulously husbanded for this service; but the world is not wise and universal benevolence does not yet bear sway.

Against the improper use and wanton waste of natural gas geologists have made earnest but unavailing protest, receiving often the curses instead of the thanks of those in whose interests they have labored. To convince the most intelligent and fair-minded members of a community of the justice and wisdom of the geological view is an easy task; but the thoughtful and fair-minded are never in the majority. Under existing conditions it is simply impossible, at least in this country, to save a promising gas field for the highest uses. Natural gas will be mainly consumed in steam production, iron mills, machine shops, glass factories, zinc smelting works, or even in the coarser service of brick yards and lime kilns. Let us still hope, however, that its use will incidentally educate enough people to the inexpressible advantages of gaseous fuel to pave the way for the introduction of a successor, necessarily a vastly inferior successor, but one which can be held under proper control, and which, therefore, when it comes, will "come to stay," except as it is improved by the growing knowledge of the world. 